NBER WORKING PAPER SERIES

\title{
WHY IS THERE SO LITTLE MONEY IN U.S. POLITICS?
}

\author{
Stephen Ansolabehere \\ John M. de Figueiredo \\ James M. Snyder, Jr. \\ Working Paper 9409 \\ http://www.nber.org/papers/w9409 \\ NATIONAL BUREAU OF ECONOMIC RESEARCH \\ 1050 Massachusetts Avenue \\ Cambridge, MA 02138 \\ December 2002
}

The views expressed herein are those of the authors and not necessarily those of the National Bureau of Economic Research.

(C) 2002 by Stephen Ansolabehere, John M. de Figueiredo, and James M. Snyder. All rights reserved. Short sections of text not to exceed two paragraphs, may be quoted without explicit permission provided that full credit including, (C) notice, is given to the source. 
Why Is There So Little Money in U.S. Politics?

Stephen Ansolabehere, John M. de Figueiredo, and James M. Snyder

NBER Working Paper No. 9409

December 2002

JEL No. H4, K0, P1

\section{ABSTRACT}

In this paper, we argue that campaign contributions are not a form of policy-buying, but are rather a form of political participation and consumption. We summarize the data on campaign spending, and show through our descriptive statistics and our econometric analysis that individuals, not special interests, are the main source of campaign contributions. Moreover, we demonstrate that campaign giving is a normal good, dependent upon income, and campaign contributions as a percent of GDP have not risen appreciably in over 100 years; if anything, they have probably fallen. We then show that only one in four studies from the previous literature support the popular notion that contributions buy legislators' votes. Finally, we illustrate that when one controls for unobserved constituent and legislator effects, there is little relationship between money and legislator votes. Thus, the question is not why there is so little money politics, but rather why organized interests give at all. We conclude by offering potential answers to this question.

Stephen Ansolobehere Department of Political Science

MIT, E53-461

50 Memorial Drive

Cambridge, MA 02142

sda@mit.edu

James M. Snyder

Department of Economics

MIT, E53-461

50 Memorial Drive

Cambridge, MA 02142

millett@mit.edu
John M. de Figueiredo

Sloan School of Management

MIT, E52-545

50 Memorial Drive

Cambridge, MA 02142-1347

and NBER

jdefig@mit.edu 
Two extreme views bracket the range of thinking about the amount of money in U.S. political campaigns. At one extreme is the theory that contributors wield considerable influence over legislators. Even modest contributions may be cause for concern and regulation, given the extremely large costs and benefits that are levied and granted by government. An alternative view holds that contributors gain relatively little political leverage from their donations, since the links from an individual campaign contribution to the election prospects of candidates and to the decisions of an individual legislators are not very firm. ${ }^{2}$ Although these theories have different implications, they share a common perspective that campaign contributions should be considered as investments in a political marketplace, where a return on that investment is expected.

In this paper, we begin by offering an overview of the sources and amounts of campaign contributions in the U.S. In light of these facts, we explore the assumption that the amount of money in U.S. campaigns mainly reflects political investment. We then offer our perspective that campaign contributions should be viewed primarily as a type of consumption good, rather than as a market for buying political benefits. Although this perspective helps to explain the levels of campaign contributions by individuals and organizations, it opens up new research questions of its own.

Sources and Sums of Campaign Contributions

For most of the last century, campaign contributions have been regulated in the United States. In 1911, Congress banned corporate contributions to parties and candidates and provided for disclosure of expenditures and contributions. Over the subsequent 60 years, that ban was extended to other organizations, including unions and trade associations. But these rules lacked 
enforcement and were far from comprehensive. Individuals, for instance, could give unlimited amounts.

The Federal Election Campaign Act of 1974 (FECA) created a comprehensive system of disclosure and contribution limits. Under FECA, there are two main types of campaign organizations: candidate campaign committees and party committees. FECA also specifies two sources of funds: individuals and interest groups, which in turn may include firms, unions, trade associations and other interest groups. (Parties and candidates may also give to each other, but such transfers account for a trivial percent of total funds.) It is also permissible for individuals and groups to raise their own money and to run their own advocacy or independent campaigns on behalf of or against individual candidates, but in practice such campaign expenditures pale in comparison with the activities of candidates and political parties. Candidates, party committee and any individuals and groups must report all contributions, receipts, and expenditures to the Federal Elections Commission (FEC).

FECA constrains how money can be raised and how much can be given. Sorauf (1988, 1992) provides an excellent overview of the FECA system and its rules. Briefly, the rules are as follows.

First, to ensure transparency in accounting, organizations wishing to contribute to federal candidates and parties must create "separate and segregated funds," commonly known as political action committees (PACs). Organizations may cover the start-up, administrative and fund-rising expenses of their PACs, but they may not give money directly from the organization's treasury to the PAC for the purpose of contributing to a federal campaign. Instead, PACs must raise voluntary donations from individuals. Thus, corporate PAC contributions come almost entirely from a corporation's managers, while union PAC 
contributions come almost entirely from their members, including dues. Corporations and unions may indirectly subsidize their PACs by paying for overhead. But, individuals are the ultimate source of all PAC contributions.

Second, individuals, PACs, and party committees can give only limited amounts directly to federal candidates and committees. PACs may give $\$ 10,000$ in a two-year election cycle to a candidate $(\$ 5,000$ each calendar year). Party committees may give no more than $\$ 17,500$ to a candidate in a two-year election cycle. Individuals may give no more than $\$ 2,000$ to a candidate in an election cycle $(\$ 1,000$ each calendar year), no more than $\$ 5,000$ to a PAC in a calendar year, and no more than $\$ 20,000$ to a party committee in a calendar year. An individual may give no more than $\$ 25,000$ total in a calendar year. The 2002 Bi-Partisan Campaign Reform Act altered the limits and tied them to inflation. At the time of this writing, the BCRA is subject to numerous court challenges.

Third, presidential candidates may receive public funds if they agree to abide by spending limits. General election candidates may receive complete federal funding; primary election candidates may receive public funds to match privately raised contributions. The Federal Election Campaign Act of 1974 the general election spending limit at \$20 million for the 1976 election, and this limit increases with the consumer price index.

A fourth set of constraints created by the Federal Election Campaign Act of 1974 limited candidate and group campaign expenditures. In 1976, the Supreme Court struck down spending limits as a violation of free speech in Buckley v. Valeo (424 US 1 (1976)). Presidential spending limits survived judicial scrutiny because they are voluntary: any candidate who wishes to receive federal funding must abide by the limits. 
Two important loopholes in the constraints have received extensive criticism. The first loophole, created by court decisions, is referred to as "independent expenditures." The Buckley decision of the U.S. Supreme Court allows individuals, groups, and corporations to spend unlimited amounts on behalf of or against a candidate, as long as such expenditures are not coordinated with candidate or party campaigns.

The second loophole, created by a series of Federal Elections Commission rulings in 1978 and 1979, created a distinction between "hard money" and "soft money." "Hard" contributions must abide by the spending limits. "Soft money" is raised through national party organizations for non-federal accounts and is to be spent on non-federal election activities, such as races for governor. Individuals and groups may give unlimited amounts to non-federal party funds for the purpose of party building activities. Such funds, it was hoped, would strengthen party organizations in the individual states. In fact, soft money has become an accounting convention used by the national party organizations to raise money. Although unlimited in amount, independent expenditures and soft party donations must still be publicly disclosed. A further loophole allows legislators to set up "leadership PACs" which allow donors to give up to $\$ 10,000$ to a candidate, but such funds cannot be used on that candidate's campaigns.

Congress reestablished FECA in 1976, and amended it again in 1979 and 2002. The 1979 amendments prohibited personal use of campaign funds by candidates or their families. The 2002 amendments place restrictions on soft money but raise the limits on hard money party contributions.

Although the loopholes of "independent expenditures," "soft money," and "leadership PACs" receive considerable attention, almost all campaign money actually comes in the form of 
"hard" contributions that must abide by the spending limits, and almost all of these funds come ultimately from individuals. The 2000 elections illustrate this pattern.

Candidate and party committees raised nearly $\$ 3$ billion during the 1999-2000 election cycle. Congressional candidates raised and spent just over $\$ 1$ billion in the 2000 election. Presidential candidates raised and spent just over $\$ 500$ million. The hard and soft money accounts of political parties totaled $\$ 1.2$ billion. ${ }^{3}$ PACs raised $\$ 600$ million, approximately $\$ 320$ million of which was for fundraising and other expenses and \$20 million of which was devoted to independent expenditures; the remainder was contributed to congressional candidates.

The majority of this money came from individuals in small amounts. We estimate that of the $\$ 3$ billion, individuals contributed nearly $\$ 2.4$ billion, the public treasury paid $\$ 235$ million in matching funds, and about $\$ 380$ million came directly from the treasuries of corporations, unions, and other associations (in the form of soft money or independent expenditures). ${ }^{4}$ Furthermore, campaign money comes mainly in small amounts. According to survey research, in the 2000 election approximately 10 percent of the Americans over the age of 18 -- 21 million people -- gave to political candidates, party committees, or political organizations (Burns et al, 2001). Thus, the average contribution from an individual to a candidate, party committee or PAC, then, is approximately $\$ 115$ ( $\$ 2.4$ billion in individual contributions divided by 21 million people). Of the estimated $\$ 2.4$ billion in individuals' contributions, about $\$ 1.1$ billion takes the form of direct contributions to congressional and presidential candidates; $\$ 700$ million goes to the parties; and $\$ 600$ million goes to PACs.

Much of the academic literature and public discussion focuses on interest groups and their PACs, so they deserve a closer look. Approximately 4,500 PACs are registered with the Federal Election Commission. In the 2000 election, 3,000 PACs gave to federal candidates or 
parties or engaged in some form of independent expenditure campaign; the remaining one-third were inactive. The number of active PACs has declined by 12 percent since 1988. Among the active PACs, 1,400 are associated with corporations, 670 are tied to a membership or industry group (such as the American Medical Association), and 240 are associated with labor unions. Another 670 are ideological groups.

While this may seem like a large number of organizations, a large number of firms and groups avoid campaign giving. Only 60 percent of the Fortune 500 companies even have PACs. To be ranked in the Fortune 500, a company must have revenues in excess of $\$ 3$ billion a year, and any company of this size is surely all are affected by government policies. Roughly one-third of all industries, coded at the 3 digit-SIC level, have no firms with PACs (see Grier, et al., 1994).

Perhaps the most surprising feature of the PAC world is the fact that the constraints on contributions are not binding. Only 4 percent of all PAC contributions to House and Senate candidates are at or near the $\$ 10,000$ limit. The average PAC contribution is $\$ 1,700$. Corporate PACs give an average contribution of approximately $\$ 1,400$ to legislators; trade associations and membership PACs give average contributions of approximately $\$ 1,700$, and labor union PACs give average contributions of $\$ 2,200$. If donors reached the maximum allowed amount, PACs would have given six times as much as they do, or nearly $\$ 2$ billion. This calculation assumes that PACs give the maximum to candidates to whom they already give money, but the modal contribution is, in fact, 0 . If all 2300 active corporate, labor and trade PACs gave the maximum amount to all incumbents running for reelection to the House or Senate (about 420 candidates), then total PAC contributions would be roughly $\$ 10$ billion -40 times more than what these PACs actually gave in the 2000 election. 
Further evidence of the slack in interest group donations to politics is seen upon comparing PACs' contributions and their total disbursements. In 2000, PACs spent $\$ 579.4$ million on all operations. Of that, $\$ 280.8$ million was contributed directly or spent on behalf of candidates. The remaining $\$ 300$ million went for overhead, operations, and other political activities (such as communications with members), which could have been paid for from the organizations treasuries directly. Were they to cover the overhead of their PACs, corporations, trade associations, and unions could almost double the amount that they contribute to political campaigns without raising an additional dollar from their managers or members.

It is evident that individuals, rather than organizations, are by far the most important source of campaign funds. In congressional elections, where PACs are most active, candidates raised over three times more from individuals directly than they did from PACs. PACs themselves receive their funds primarily from individuals.

Campaign Contributions as a Political Investment

Campaign fundraising is widely viewed as a market for public policy. Donations come from firms, associations, and individuals that seek private benefits in the form of subsidies, favorable regulations and other policies set by the government. With thousands of interests bidding for private benefits and thousands of candidates vying for funds, something like a market for legislation emerges. As with any competitive market, the rate of return on the investment in politics should resemble that of other investments. Relatively recent research that posits that campaign finance reflects a competitive market for private benefits from public laws or for 
services and effort from politicians includes Denzau and Munger (1986), Baron (1989), Snyder (1990), Baron and Mo (1991), and Grier and Munger (1991).

A related strain in the theoretical literature on campaign contributions posits that there is a market failure in politics that gives legislators more of the bargaining power. Grossman and Helpman (1994) examine a range of cases, including this one. In particular, legislators hold key "gatekeeping" positions, and can threaten regulation or harassing oversight unless interest groups contribute. In such a world, legislators can receive very large political donations without changing public policy much.

There is ample research documenting behavior consistent with this view. Legislators who are committee chairs or who serve on powerful committees raise substantially more than other members, and legislators who are party leaders raise significantly more than backbenchers (Grier and Munger, 1991; Romer and Snyder, 1994; Ansolabehere and Snyder, 1999). Also, economic PACs give donations in ways that fit with a simple arbitrage pricing model: economic PAC contributions are pegged to the odds that a politician will win a seat, while donations from individuals and ideological PACs are not (Snyder 1990).

However, a critical weakness with the view that campaign contributions are investments appears once we look at the broad patterns of political giving and government spending.

\section{Tullock's Puzzle}

Considering the value of public policies at stake and the reputed influence of campaign contributors in policymaking, Gordon Tullock (1972) asked, why is there so little money in U.S. politics? In 1972, when Tullock raised this question, campaign spending was about \$200 million. Assuming a reasonable rate of return, such an investment could have yielded at most $\$ 250-300$ 
million over time, a sum dwarfed by the hundreds of billions of dollars worth of public expenditures and regulatory costs supposedly at stake.

Over the past three decades, Tullock's puzzle has not disappeared. Candidates, parties, and organizations raised and spent $\$ 3$ billion in the 2000 national elections. However, total federal government spending in 2000 equaled $\$ 2$ trillion; consumption and gross investment of the federal government was $\$ 590$ billion; and the actual and potential costs of compliance with regulations were surely worth hundreds of billions of dollars as well.

The puzzle comes into sharper focus still when we examine specific interests and policies. ${ }^{5}$ For example, all defense contracting firms and individuals associated with those firms gave approximately $\$ 10.6$ million to candidates and parties in 1998 and $\$ 13.2$ million in 2000 . The U.S. government spent approximately $\$ 134$ billion on defense procurement contracts in fiscal year 2000 (U.S. Census Bureau, 2000). Firms, individuals, and industry associations of the oil and gas industry gave \$21.6 million to candidates and party organizations in 1998 and $\$ 33.6$ million in 2000. The Energy Information Administration (1999) of the U.S. Department of Energy values subsidies to the energy industry in 1999 at $\$ 1.7$ billion. In agriculture, crop producers and processors contributed $\$ 3.3$ million to candidates and parties in 2000; U.S. commodity loans and price supports equaled $\$ 22.1$ billion that year (U.S. Department of Agriculture website). Dairy producers, who since 1996 have had to have subsidies renewed annually, gave $\$ 1.3$ million in 2000 and received price supports worth almost $\$ 1$ billion in the Farm Security and Rural Investment Act of 2002. In the case of sugar producers, Stratmann (1991, p. 615) estimates that a " $\$ 3,000$ sugar PAC contribution maps into a yes vote with almost certainty." Without sugar industry contributions, he further estimates, the final vote on the sugar amendment to the 1985 agriculture bill would have been 203-210, effectively ending the sugar 
subsidy. With contributions, the subsidy survived: the final vote was 267-146. A U.S. General Accounting Office (1993) study values that the annual transfer from consumers to sugar producers and processors at $\$ 1.1$ billion a year from 1989 to 1991 . In other words, a $\$ 192,000$ worth of contributions in 1985 bought more than $\$ 5$ billion worth of value for the industry over a five-year period.

The discrepancy between the value of policy and the amounts contributed strains basic economic intuitions. Given the value of policy at stake, firms and other interest groups should give more. The figures above imply astronomically high rates of return on investments. In a normal market, with such high rates of return, existing donors should want to increase their contributions. There are, of course, legal limits on what they can do. However, as noted earlier, the "hard money" constraints are rarely binding and even if they were, the loopholes for “independent expenditures" and "soft money" are available. Even those firms, associations, and unions that do give could probably double their contributions by paying for their PACs' operations. In addition, more firms and industries should enter the political marketplace. If a relatively small investment of approximately $\$ 200,000$ brings a return of $\$ 1$ billion, as in the example of the sugar industry, or even one-thousandth that amount, then investors should want to shift assets out of other investments and enter the political market. However, recall that 40 percent of Fortune 500 firms and one-third of industries don't even have a PAC.

Tullock's (1972) observation challenged the basic premise of both economic analyses of campaign finance and public discourse about reform -- that campaign contributions should be viewed as an investment in political outcomes. Such a market might exist in certain policy niches, but the relatively small amounts given imply that such a market is not determining the outcome of most public policy. It seems highly unlikely that the 21 million individual donors 
giving an average of $\$ 115$ apiece were calculating the return that they would personally receive on this investment.

One strain of theorizing in the tradition of regarding campaign contributions as a political investment does suggest that donors might receive especially high returns on their investment. In these models, donors are monopoly providers of campaign funds and legislators compete for contributions (Dal-Bo, 2001; Helpman and Persson, 2001). Such models predict that the monopoly donors can get a lot for a little. However, the assumed lack of entry makes these models seem rather unrealistic. If extraordinary rates of return can be earned through political investments, then we would expect firms, individuals, and associations to flock to campaign finance. But most firms and people do not give.

The Lack of Connection from Campaign Contributions to Legislative Behavior

Tullock's puzzle can also be stood on its head. Since most firms and people do not make political contributions, one can infer that they apparently see little return to doing so. It is easy enough to see why they might hold this belief. Any individual contribution will be only a tiny share of the overall contributions collected by a national-level politician. The contribution may or may not influence that politician. In turn, the politician, or group of politicians, who receives such contributions, may win or lose the political fight. In short, it is critical for the argument that campaign finance reflects a market for policy to find evidence that contributions have substantial effects on legislative decisions and policy outcomes. Otherwise, if one views campaign contributions in the hope of a reasonable return on investment, it may well make more sense to avoid putting money into political contributions. 
While the lack of entry raises doubts about the plausibility of such models, investment theories of political contributions hinge ultimately on two facts that one may examine empirically. First, what is the rate of return on contributions? If there is a high rate of return on political investment one might still be inclined to favor the view that donors have more of the bargaining power in their dealings with legislators. Second, who is the marginal contributor to politics? All of these models assume that legislators are highly reliant on groups for campaign funds.

There is an extensive literature that attempts to measure the political efficacy of interest group donations. Almost all research on donors' influence in legislative politics examines the effects of contributions on roll call votes cast by members of Congress. ${ }^{6}$ Dozens of studies have considered the effects of contributions on legislative votes, across hundreds of pieces of legislation. We surveyed nearly 40 articles in economics and political science that examine the relationship between PAC contributions and congressional voting behavior. Table 1 summarizes the key findings reported in these papers and some details about the analyses. Typically, these papers regresses roll call votes -- a single vote, a vote count, or vote index -- on a number of independent variables, including the PAC contributions received by the legislator. Some papers study broad issues and include broad measures such as total corporate PAC contributions and/or total labor PAC contributions. Others study narrower issues and include more narrowly defined contribution measures; for example, regressing votes on dairy price supports on contributions from dairy industry PACs. About one-third of studies use specifications with instrumental variables.

[Table 1 here] 
Setting aside questions for the moment about the right specification, what do these studies suggest? In the column headed "Number of Significant PAC Coefficients," the first number gives the number of coefficients on PAC contributions that are signed correctly and statistically significant at the 5 percent level (two-tailed), while the second number gives the total number of PAC contribution variables in the analysis. ${ }^{7}$ Overall, PAC contributions show relatively few effects on voting behavior. In three out of four instances, campaign contributions had no statistically significant effects on legislation or had the "wrong" sign -- suggesting that more contributions lead to less support. Interpreting this literature is difficult for several reasons. We are interested in the magnitude of the effect, not just statistical significance. Unfortunately, it is difficult to discern the relative magnitude and meaning of the coefficients for most of the analyses in Table 1, because few of these papers report enough information about the data, like means and standard deviations of the underlying variables, to make such an assessment possible.

In addition, the question of how to estimate the effect of contributions on votes while adjusting for other relevant factors is a difficult one, and two well-known specification issues plague most of these studies. First, there is a likely simultaneity between contributions and votes, which may bias estimates: that is, contributions may influence votes, but votes may also influence contributions. Investor theories assume that contributors are strategic. Many models predict that legislators who are undecided on a specific bill will receive more donations. True simultaneity in the data arises because some "investor" contributions may come before roll call votes, and some contributions come after roll call votes, as payment for services rendered.

Second, most analyses lack crucial control variables, such as the strength of the donor group or interest in the legislative districts. This is a serious problem because of the tendency 
for groups to contribute to "friendly" legislators or to pivotal legislators. Such strategies are welldocumented empirically and well-grounded theoretically; after all, groups may contribute in part to help re-elect their friends, and legislators from "friendly" districts may be able provide services to the groups at lower marginal cost (for example, Herndon, 1982; Poole and Romer, 1985; Grier and Munger, 1986, 1991, 1993; Poole, Romer and Rosenthal, 1987; Evans, 1988). Such strategizing means that any omitted factor that predicts roll call votes will necessarily be correlated with an interest group's contributions.

Two corrections for these problems are to use instrumental variables to untangle the simultaneity between donations and votes and to exploit the panel of roll call votes on related issues over time to better capture omitted variables. Some studies do implement these corrections.

We offer a statistical analysis here that illustrates how these studies work and what conclusions such corrections lead to. Our dependent variable is the roll call voting score produced by the Chamber of Commerce of the United States. We collected this score for the U.S. House from 1978 to 1994. Like many interest groups, the Chamber of Commerce identifies 1220 bills in each Congress that are important to its interests, and calculates the percentage of times that each member of Congress votes with the group. Scores therefore run from 0 to 100 . We conducted similar analyses for voting scores from five other organizations: the AFL-CIO, the American Security Council, the Consumer Federation of America, the League of Conservation Voters, and the National Education Association. Since the basic patterns are similar in all cases, we only report here the results for the CCUS.

We estimate six models, which cover much of the range of specifications found in the existing literature. First, we consider three different ways of controlling for district and legislator 
preferences. The first specification uses party affiliation of the member and a measure of district preferences based on voting patterns. The second specification uses political party affiliation of the member and a district-specific fixed effect. The third specification uses a legislator-specific fixed effect. The last two specifications exploit the panel structure of the data - that is, we observe most legislators several times in the sample. We believe that using legislator-specific fixed effects provides the most compelling estimates, because this controls for legislators' own (average) preferences in addition to district preferences. There is strong evidence that legislators are strongly influenced by their party and by their constituencies when casting roll call votes (for example, Poole and Rosenthal, 1984, 1997; Levitt, 1996; Ansolabehere, Snyder and Stewart, 2001). ${ }^{8}$

In addition, we estimate each specification using both ordinary least squares and instrumental variables. We follow Chappell $(1981,1982)$, Welch (1982), and others in choosing instruments. Two types of variables are used: the degree of electoral competition and measures of members' relative "power" inside the House. For electoral competitiveness, the idea is that a close race increases an incumbent's demand for PAC contributions, producing an exogenous shift in contributions via in increase in the propensity to "sell" services, including roll call votes. For the "power" of a member, the argument is that groups give more to powerful members because their support is especially valuable. The instrumental variables to measure degree of electoral competition are: total campaign spending by the opponent, the absolute value of vote-share minus .5 , and a dummy variable indicating that the member ran unopposed. The variables that measure a member's relative power are a dummy variable indicating that the member is a party leader, a dummy variable indicating that the member is a committee chair, and a dummy variable indicating that the member was on the Ways and Means or Energy and Commerce committee 
(probably the two most powerful committees with respect to business issues). The first step is to run regressions using contributions from corporate and labor PACs as the dependent variables and the collection of instrumental variables as the independent variables. The coefficients from these regressions can be used to generate predicted values of contributions from corporate and labor PACs. Then in the second stage, these predicted contributions can then be used as independent variables in the regress with vote patterns as the dependent variable.

The results are shown in Table 2. The first three columns present the ordinary least squares estimates and the second three columns present the instrumental variables estimates.

[Table 2 here]

Column 1 is similar to the most common specifications found in the literature. In this specification, contributions do appear to have significant effects on votes. Even so, the effects of contributions are quite small compared to other factors. An additional $\$ 60,000$ in corporate PAC contributions (approximately one standard deviation) changes the voting score by at most 2 points on the scale of 0-100; an additional \$50,000 in labor PAC contributions changes the voting score by 6 point. By comparison, changing the party of a district's representative changes the voting score by more than 30 points. Using instrumental variables in column 4 reduces the estimated effects of contributions substantially, and reverses the sign on corporate donations. Controlling for voters' preferences using district fixed effects almost completely eliminates the effects of contributions on legislative voting, in columns 2 and 5. Also, this specification causes the effect of a change in party to increases to 40 points. ${ }^{9}$ Using legislator fixed-effects eliminates the effects of contributions entirely, again in both sets of estimates. The estimated coefficients are tiny and statistically insignificant. Evidently, changes in donations to an individual legislator do not translate into changes in that legislator's roll call voting behavior. 
Overall, our findings parallel that of the broader literature. As regressions like these make clear, the evidence that campaign contributions lead to a substantial influence on votes is rather thin. Legislators' votes depend almost entirely on their own beliefs and the preferences of their voters and their party. Contributions explain a miniscule fraction of the variation in voting behavior in the U.S. Congress. Members of Congress care foremost about winning reelection. They must attend to the constituency that elects them, voters in a district or state, and the constituency that nominates them, the party.

This finding helps to explain Tullock's (1972) puzzle. Money has little leverage because it is only a small part of the political calculation that a reelection oriented legislator makes. And, interest group contributors - the "investors" in the political arena - have little leverage because politicians can raise sufficient funds from individual contributors. It is true that when economic interest groups give, they usually appear to act as rational investors (for example, Snyder, 1990, 1992, 1993; Grier and Munger, 1991; Romer and Snyder, 1994; Kroszner and Stratmann, 1998, 2000; Ansolabehere and Snyder, 1999, 2000a). However, this "investor" money from organized groups accounts for only a small fraction of overall campaign funds. Since interest groups can get only a little from their contributions, they give only a little. As a result, interest group contributions account for at most a small amount of the variation in voting behavior. In fact, after controlling adequately for legislator ideology, these contributions have no detectable effects on the behavior of legislators.

Nonetheless, as a statement of plain fact, there were $\$ 3$ billion worth of campaign contributions over the 1999-2000 election cycle. A majority of Fortune 500 firms do have their own PACs. Twenty-one million individuals did make contributions. These campaign 
contributions are more than trivial. If donations are not a political investment, then what are they?

Campaign Contributions as a Form of Consumption

We favor an alternative perspective on campaign contributions. In our view, campaign contributing should not be viewed as an investment, but rather as a form of consumption -- or in the language of politics, participation. Recall that almost all money in the existing campaign finance system comes ultimately from individuals and in relatively small sums. We therefore expect that the factors that determine why individuals give are the factors that drive total campaign spending. The tiny size of the average contribution made by private citizens suggests that little private benefit could be bought with such donations.

Instead, individuals give because they are ideologically motivated, because they are excited by the politics of particular elections, because they are asked by their friends or colleagues, and because they have the resources necessary to engage in this particular form of participation. In short, people give to politics because of the consumption value associated with politics, rather than because they receive direct private benefits. Those who give to politics are also disproportionately likely to participate in other ways, including attending meetings, writing letters, talking to others, and voting (Rosenstone and Hansen, 1992; Verba, Schlozman, and Brady, 1995). We call these donors "consumer contributors." They account for most of the campaign money in politics.

Political giving should be regarded as a form of consumption not unlike giving to charities, such as the United Way or public radio. Economic theory predicts relatively little about 
such consumption goods, except that like any normal good they will grow with income. Indeed, survey researchers in political science and sociology have documented that income is by far the strongest predictor of giving to political campaigns and organizations, and it is also the main predictor of contributing to nonreligious charities. Individuals give relatively little to politics, much less than to charities.

The notion that campaign contributions mainly reflect consumption and participation of many individuals suggests that personal income should determine the amount raised and spent in campaigns. Alternatively, a basic prediction of models that view campaign contributions as political investments in rent-seeking is that total government spending should explain total campaign spending. The growth of government over the last 60 years, the argument goes, has meant that government regulations, taxes and subsidies, and other policies, can have substantial effects on private interests. The threat of regulation or other unfavorable treatment may also induce private interests to give to politics. As a result, the more government spends, the more private interests must contribute (Lott, 2000).

To test these predictions, we consider a range of evidence: a look at the political contributions of highly paid executives; a time series of campaign spending under the Federal Election Campaign Act from 1978 to 2000; a time series of candidate and party expenditures in presidential elections from 1884 to 2000; panel data of campaign spending by gubernatorial candidates from 1976 to 2000; and cross-section data on spending in House of Representatives elections in recent decades. The FECA data on recent elections offers the best accounting of campaign spending. The presidential election series offers a very long time series, but the quality of the data is less good. The state data offers the advantage of a panel, with enough observations to allow us to test competing hypotheses. In general, the evidence suggests that campaign 
spending tracks income and electoral competition (that is, demand for money), rather than government spending.

The Political Giving of Top Corporate Executives

The contribution behavior of top corporate executives illustrates the importance of income. We examined the political contributions of 94 top executives from 12 large corporations -- some of the wealthiest people in America. ${ }^{10}$ On average, these executives gave $\$ 3,000$ to their own corporations' political action committees in the 1997-1998 election cycle. They gave an additional $\$ 4,500$ to candidates, parties, and other committees, for an average total political contribution of $\$ 7,500$ per executive, far below the $\$ 25,000$ allowed under the Federal Election Campaign Act. Dividing by their annual compensation, these executives gave $\$ 51$ for every $\$ 100,000$ of income each year. In other words, top corporate executives gave about 0.05 percent of their annual compensation to political campaigns. This 0.05 percent figure slightly overstates the share of the income of top executives devoted to politics, because we do not include income from capital gains, dividends, and interest. What is striking about this figure is that it is nearly the same as the overall share of national income devoted to political campaigns in 2000, 0.04 percent.

As with the public at large, giving to charity is much more important to firms and executives than giving to politics. Milyo, Primo, and Groseclose (2000) studied 15 large corporations in 1998 . The firms in their sample gave $\$ 1,611$ million to charities and just $\$ 16$ million to political campaigns. The response to the terrorist attacks of September 11, 2001, also suggests that campaign contributions might be properly viewed simply as one item in a portfolio 
of voluntary donations. Stevens (2001) reports that political contributions dropped significantly in the month following $9 / 11$, as individuals diverted their funds to various charities.

Time Series Evidence on Campaign Spending

Charitable contributions account for a fairly constant share of national income (about 2 percent). Does campaign spending grow with income, like other forms of "consumption giving"?

The growth of campaign spending is shown in Figure 1. Figure 1a graphs the trend in real campaign spending under the FECA regime (to the right of the vertical line). The numbers reported encompass all hard and soft money, as well as public funds. Real campaign spending has indeed grown, roughly doubling between 1976 and 2000. Since the price of most campaign inputs, such as labor and advertising prices, grow with the consumer price index, this higher spending primarily reflects an increase in real campaign outlays. From our perspective, however, price inflation is not the right baseline against which to measure the growth in campaign spending. A more appropriate baseline is national income, shown in Figure 1b. Over the period 1976-2000 (shown to the right of the vertical line in the figure), there is no trend in campaign spending relative to national income. Ansolabehere, Gerber, and Snyder (2001) examine trends in individual, PAC, and party contributions. After deflating each type of money by GDP, no trends are evident within each category of campaign money.

[Figure 1 here]

Reports of the presidential campaign spending by candidates and by political parties' campaign committees are fairly complete from 1912 on, although most congressional candidates did not file reports until the Federal Elections Campaign Act of 1974. However, histories of 
significant political campaigns have reconstructed the budgets of the earlier presidential campaigns and party committees going back to 1884 ; Alexander (1984, p. 7) presents a table with these figures.

Figures $1 \mathrm{a}$ and $1 \mathrm{~b}$ also display a long-run perspective on expenditures in presidential campaigns by candidates and parties. The long-run perspective parallels the lessons from more recent decades. Real campaign spending has grown sharply, although somewhat more irregularly, over the last 120 years. However, campaign spending as a fraction of national income has shown no growth at all.

The two most dramatic features of Figure $1 \mathrm{~b}$ in the long-term are the collapse in spending during the first decade of the twentieth century and the rough stability since. Measured relative to national income, presidential campaigns in the 1880s and 1890s spent three times more than the typical presidential campaigns since then. The 1890s and 1900s ushered in wide ranging political reforms, including the secret ballot that made vote-buying during elections nearly impossible, civil service and government spending reforms that limited the powers of political machines, and campaign finance reform. From 1912 to 2000, presidential campaigns have accounted for approximately the same, small fraction of GDP. This pattern suggests that the private benefits bought through the campaign finance system are at least not an increasing problem for our economy.

State Gubernatorial Elections from 1976 to 2000

Using the time series data, it is impossible to distinguish whether presidential campaign spending is more affected by income growth, as in our thesis that campaign contributions are a form of consumption, or by the growth of government spending growth, as in the thesis that 
campaign spending is a political investment. The correlation between real per capita GDP and real per-capita federal spending is .98 , and even the long historical series contains just 23 observations. However, state elections allow us to untangle the effects of income, government spending, and electoral competition.

We have compiled a fairly complete panel of spending in gubernatorial elections from 1976 to 2000. Data on campaign contributions, campaign expenditures, and election results comes from the Gubernatorial Campaign Expenditures Database, compiled by Thad Beyle and Jennifer M. Jensen, and from America Votes (various years). To our knowledge, this is the most comprehensive data set that exists on aggregate gubernatorial campaign spending. We also used data on personal income from the Bureau of Economic Analysis (<http://www.bea.doc.gov/bea/regional/data.htm) and state government expenditure data from the Compendium of State Government Finances produced by the U.S. Census Bureau.

It is difficult to compare campaign spending levels across states, because states operate under different regulatory regimes. Some states have no limits on contribution or expenditure levels (Alaska, Pennsylvania, Utah), while others have relatively strict limits that have been in place for many years. Some states allow direct corporate and labor contributions (Illinois, New Mexico) while others do not. Some states have generous public funding mechanisms (Michigan, New Jersey). Instead of comparing across states, we can exploit the panel structure of the data and compare changes in spending and other variables over time within states.

Table 3 presents a statistical analysis of the panel of campaign spending on gubernatorial races from 1976 to 2000 . The dependent variable is total spending per capita in gubernatorial elections. The independent variables shown in the table are personal income per capita, government spending per capita, and three measures of general and primary election 
competition. Closeness in General Election is defined as $1-\mathrm{v}_{\mathrm{G}}$, where $\mathrm{v}_{\mathrm{G}}$ is the winning candidate's vote share in the general election. Average Closeness in First Primary is the average of $1-v_{D}$ and $1-v_{R}$, where $v_{D}$ is the winning candidate's vote share in the first Democratic primary election and $\mathrm{v}_{\mathrm{R}}$ is the winning candidate's vote share in the first Republican primary election. Average Closeness in Second Primary is defined analogously. The winning candidate's vote share is 1 in uncontested races. The spending and population figures are in logarithms, so the coefficients can be interpreted as elasticities. The regression includes fixed effects for each state to allow for differences in state campaign laws and other unmeasured state effects.

[Table 3 here]

Personal income and the electoral competition variables strongly predict spending on state gubernatorial races. The coefficient on $\log$ of per capita income is approximately equal to 1 , consistent with the findings above that the share of income spent on campaigns is constant. ${ }^{11}$ The average within-state correlation between income and government spending is .86 in this data, but when income is taken into account, government spending has no independent effect on total campaign spending. Using the coefficients in Table 3, one can calculate that growth of per capita income and of population explain nearly all of the growth in per-capita campaign spending in the states. The effect of income growth on predicted levels of campaign spending is roughly four times larger than the effect of population growth.

Electoral competition has a strong positive effect on total spending. However, gubernatorial elections were, on average, more competitive in the 1970s than in the 1990s, and there were fewer seats for which incumbents stood for election during the 1990s. Thus, the trend in electoral competition cannot explain the growth in campaign spending. Rather, the reduced 
level of competition in races for state governor during the 1990s would have predicted a lower level of spending in these campaigns.

Cross-Sectional Analysis of Congressional Elections

Looking across elections to the House of Representatives and to the Senate (from 1992 to 2000) teaches a similar lesson about the importance of income and the competitiveness of elections.

During the 1990s, the average House election cost $\$ 810,000$ (Democratic and Republican candidate spending combined), but spending varied considerably across districts. Per capita income in congressional districts ranges from a low of $\$ 7,000$ to a high of $\$ 41,000$, with an average of $\$ 15,000$. During the 1990 s, total campaign spending averaged about $\$ 700,000$ in lowincome districts, defined as per capita income below $\$ 13,000$ (43 percent of all House seats); campaign spending averaged $\$ 850,000$ in middle income districts, with per-capita income between $\$ 13,000$ and $\$ 19,000$ (45 percent of the cases); and it averaged about $\$ 1,000,000$ in high income districts, with per capita income above $\$ 19,000$ (12 percent of the cases). These figures are displayed on the bottom margin of Table 4, which presents total campaign spending in the typical House race for each of the three income categories and each of four categories of vote margin.

\section{[Table 4 here]}

Competitiveness of the House race has even stronger effects on total spending than district income. The typical House election in the 1990s was decided by 17 percentage points, but many races were determined by much smaller margins. During the 1990s, total spending averaged $\$ 1,300,000$ in House elections decided by fewer than 5 percentage points; $\$ 980,000$ in 
House elections decided by 5 to 15 percentage points; $\$ 570,000$ in elections decided by 15 to 30 percentage points; and $\$ 396,000$ in elections decided by more than 30 percentage points.

To measure these effects and control for other factors, we set up a regression with total spending on the congressional race as the dependent variable. The explanatory variables were district income and extent of electoral competition, along with year, party, and incumbency. Holding constant the competitiveness of the race, an additional $\$ 1,000$ dollars of per capita income in a district translates into an additional $\$ 20,000$ of total campaign spending. ${ }^{12}$ Holding constant district income, a 1 percentage point reduction in the electoral margin between the candidates corresponds to an increase in combined total spending of $\$ 20,000$.

The Marginal Dollar

One final piece of evidence pointing toward the central importance of the small, consumer contributor in politics is how candidates' fundraising changes as their demand for money grows.

Individual donors grow in importance as demand for campaign cash increases. In safe House seats, those decide by a margin of 30 percentage points or more, 48 percent of campaign funds came from individuals and 46 percent from PACs. In close House races, those decided by fewer than 5 percentage points, 60 percent of campaign funds came from individuals and 31 percent came from PACs. Most of the difference in the share from individuals is accounted for by contributions in amounts less than $\$ 500$. On the margin, then, candidates raise disproportionately more from individuals than from interest groups.

A more dramatic pattern holds in U.S. Senate elections. The average U.S. Senate candidate receives approximately $\$ 1$ to $\$ 2$ million from interest groups, and this amount varies 
somewhat with state size. Total PAC contributions to California Senate elections (Democrat and Republican candidates combined) average of \$2 million from PACs during the 1990s. Total PAC contributions to Wyoming and North Dakota Senate elections received an average of $\$ 950,000$ from PACs during the 1990s.However, California Senate elections are much more expensive than elections in Wyoming and North Dakota, mainly because California is both wealthier and more populous than Wyoming and North Dakota. The typical U.S. Senate election in California during the 1990s cost \$24 million, while the typical U.S. Senate election in small states cost \$2 million total in the 1990s. The difference is accounted for almost entirely by individual contributors. Snyder (1993) and Ansolabehere and Snyder (1999) present a more comprehensive and detailed analyses of House and Senate elections.

This suggests that small individual donors contribute not only the average dollar in politics, but the marginal dollar as well. When increased demand for campaign funds induces candidates to raise additional funds, they turn not to political action committees or even large individual donors, but to small individual donors, who give an average of about $\$ 100$. This fact runs contrary to the fundamental assumption of all investor models of politics - that politicians rely principally on interest groups and large individual donors for their campaign funds. Any theory of political giving, then, must place the small individual contributor, whose motivations reflect the consumption value of being involved in politics rather than the potential return on the investment, at the center of the campaign finance system.

\section{A Research Agenda on Campaign Contributions}


Much of the academic research and public discussion of campaign contributions appears to be starting from some misguided assumptions. Campaign spending, measured as a share of GDP, does not appear to be increasing. Most of the campaign money does not come from interest group PACs, but rather from individual donors. Most donors give substantially less than the current hard money limits. It doesn't seem accurate to view campaign contributions as a way of investing in political outcomes. Instead, aggregate campaign spending in the United States, we conjecture, mainly reflects the consumption value that individuals receive from giving to campaigns. In addition, individual contributors provide the average and the marginal dollar to political campaigns. Because politicians can readily raise campaign funds from individuals, rentseeking donors lack the leverage to extract large private benefits from legislation.

These arguments suggest a reorientation of future research on campaign finance. Different issues arise for individual and for interest group campaign contributions.

On the subject of individual campaign contributions, the idea of a campaign contribution as a form of consumption needs more empirical and theoretical development. As with other forms of voluntary public-spirited activities such as giving to charities or voting, the theoretical underpinnings of small campaign donations are not well understood. It is unclear what specific empirical predictions distinguish consumption from rent-seeking, or what evidence will prove compelling. Consumption might take many forms, including expression, citizen duty, and social life. Do fundraising strategies of PACs look like those of charitable organizations or like those of venture capitalists? Charities hold events, bring in speakers with as much celebrity status as possible, and conduct mass-mail drives. If campaign contributions are a form of expression, then we might expect certain types of people to give to like types of candidates and organizations. 
Does this pattern hold? Are contributors more interested in politics on a personal level than other citizens? Is politics an important part of their social life?

A second set of issues is that individual campaign contributions may still have significant effects on legislative decisions policies, but their influence might be more akin to the importance given to certain demographic groups within the electorate. To raise sufficient funds, candidates might skew policies in ways preferred by individual donors. Since campaign contributions are so closely linked to income, campaign contributions might act like weighted votes. Contributors who are disproportionately wealthy might have different policy preferences than the median voter. Whether this has significant effects on policy is unknown. Fleshing this out requires careful study of how policy responds to the preferences of contributors and the overall level of contributions.

From the standpoint of interest group giving, the question is not why do corporations, unions, and other interest groups give so little, but why do they give at all? Why do they form PACs? Why do they behave so strategically? We think there are four possible answers, each deserving of further exploration.

One possible answer is that interest groups give a little and get a little. Although aggregate campaign expenditures primarily reflect consumption, it may be that a subset of donors, mainly corporate and industry PACs, behave as if they expected favors in return. These contributors may in fact receive a reasonable rate of return -- say 20 percent -- but their investments do not account for most of campaign contributions, nor do they explain much government activity.

A second answer is that money buys access, rather than policy directly. Legislators and their staffers are busy people. Campaign contributions are one way to improve the chances of 
getting to see the legislator about matters of concern to the group. One estimate is that one hour of a legislator's time costs around $\$ 10,000$ (Langbein, 1986). There is some evidence that campaign contributions are tied to lobbying activities (Sabato, 1984). Groups that give large amounts to political campaigns also emphasize lobbying (Ansolabehere, Snyder and Tripathi, 2002). The Lobby Reform Act of 1995 provides for disclosure of expenditures on executive and legislative lobbying. In 1997-1998, interest groups spent $\$ 3$ billion on lobbying, about 10 times the $\$ 300$ million that they spent on PAC contributions (Ansolabehere, Snyder and Tripathi, 2002). Clearly, many interest groups are showing by their behavior that lobbying is more important than campaign contributions. Of course, access itself does not guarantee influence, but only the opportunity to provide information that might influence legislators. ${ }^{13}$

A third explanation is that interest groups seek to affect elections - that is, to elect legislators that are sympathetic to their views and defeat legislators known to be hostile -rather than to change the views of existing legislators. Helping to elect friends might have much larger marginal effects on legislation than trying to buy support from those already in Congress. Our analysis of roll call voting above reveals that who is in the legislature, a Republican or a Democrat, has an enormous effect on support for a range of policies of importance to groups. Why doesn't this connection lead groups to contribute untold billions of dollars to friendly candidates? There are two reasons. First, statistical analyses estimate that the marginal effect of an additional $\$ 100,000$ of campaign spending is quite small, probably no more than 1 percentage point in the vote in the typical House race even in the observed ranges (for example, Jacobson, 1980; Levitt, 1994). Second, collective action problems abound, leading to under investment in activities that may benefit, say, a certain industry as a whole. 
A fourth possibility is that PACs coordinate individual donations and help overcome collective action problems that might otherwise plague individual contributors. Marx and Matthews (2000) present an interesting model that might be applicable.

A final possibility is that even interest groups give for consumption. PAC contributions are solicited at events attended by prominent national politicians -- people of celebrity status. Organizations' executives and managers may value being part of the Washington establishment. Whatever the reasons that groups give, one central fact remains. Individuals are the main source of money in U.S. campaigns, and their presence mutes the political leverage of interest groups. If individuals were less willing to contribute than they are, then interest group money could be more pivotal for elections and policy-making. In a way, then, the 20 million individuals in the United States protect themselves from special interest power with their donations of about one hundred dollars each. 
Acknowledgements

Professor Ansolabehere thanks the Carnegie Corporation for their generous financial support under the Carnegie Scholars Program. 


\section{References}

Alexander, Herbert E. 1984. Financing Politics. Washington DC: CQ Press.

Ansolabehere, Stephen and James M. Snyder, Jr. 1999. "Money and Institutional Power." Texas Law Review 77: 1673-1704.

Ansolabehere, Stephen and James M. Snyder, Jr. 2000a. "Money and Office.” In Continuity and Change in Congressional Elections, edited by David Brady and John Cogan. Stanford, CA: Stanford University Press.

Ansolabehere, Stephen, and James M. Snyder, Jr. 2000b. "Soft Money, Hard Money, Strong Parties.” Columbia Law Review 100: 598-619

Ansolabehere, Stephen, Alan Gerber, and James M. Snyder, Jr. 2001. “Corruption and the Growth of Campaign Spending." In A User's Guide to Campaign Finance Reform, edited by Gerald C. Lubenow. New York: Rowman and Littlefield.

Ansolabehere, Stephen, James M. Snyder, Jr., and Charles Stewart, III. 2001. "Candidate Positioning in U.S. House Elections.” American Journal of Political Science 45: 136159.

Ansolabehere, Stephen, James M. Snyder, Jr., and Micky Tripathi. 2002. “Are PAC 
Contributions and Lobbying Linked? New Evidence from the 1995 Lobby Disclosure Act.” Business and Politics, forthcoming.

Bailey, Michael. 2002. "Do Campaign Contributions Lead to Policies That Favor the Wealthy? An Examination of Taxing and Spending in the American States." Unpublished manuscript, Georgetown University.

Baron, David P. 1989. "Service-Induced Campaign Contributions and the Electoral Equilibrium.” Quarterly Journal of Economics 104: 45-72.

Baron, David P. 1991. "Campaign Contributions and Party-Candidate Competition in Services and Policies." In Political Economy: Institutions, Competition, and Representation, edited by W.A. Barnett, M.J. Hinich, and N.J. Schofield. Cambridge: Cambridge University Press.

Bronars, Stephen G., and John R. Lott, Jr. 1997. "Do Campaign Donations Alter How a Politician Votes? Or, Do Donors Support Candidates Who Value the Same Things That They Do?" Journal of Law and Economics 40: 317-350.

Burns, Nancy, Donald R. Kinder, Steven J. Rosenstone, Virginia Sapiro, and the National Election Studies. American National Election Study, 2000: Pre- and Post-Election Survey. [Computer file]. 2nd ICPSR version. Ann Arbor, MI: University of Michigan, Center for 
Political Studies, 2001. Available as the Inter-university Consortium for Political and Social Research, Study 3131, at http://www.icpsr.umich.edu/.

Chappell, Henry W., Jr. 1981. "Campaign Contributions and Voting on the Cargo Preference Bill: A Comparison of Simultaneous Models." Public Choice 36: 301-312.

Chappell, Henry W., Jr. 1982. "Campaign Contributions and Congressional Voting: A Simultaneous Probit-Tobit Model.” Review of Economics and Statistics 62: 77-83.

Coughlin, Cletus C. 1985. "Domestic Content Legislation: House Voting and the Economic Theory of Regulation.” Economic Inquiry 23: 437-448.

Dal-Bo, Ernesto. 2001. "Bribing Voters.” Unpublished manuscript, Oxford University.

de Figueiredo, John M. and Brian S. Silverman (2002). "Academic Earmarks and the Returns to Lobbying," Working Paper \#9064. Cambridge, Mass.: National Bureau of Economic Research.

Denzau, Arthur T., and Michael C. Munger. 1986. "Legislators and Interest Groups: How Unorganized Interests Get Represented.” American Political Science Review 80: $89-106$.

Durden, Garey C., Jason F. Shogren, and Jonathan I. Silberman. 1991. "The Effects of Interest Group Pressure on Coal Strip-Mining Legislation.” Social Science Quarterly 
72: $239-250$.

Energy Information Administration. 1999. Federal Financial Interventions and Subsidies in Energy Markets 1999: Primary Energy, September 1999, U.S. Department of Energy, Washington DC.

Evans, Diana. 1986. "PAC Contributions and Roll-Call Voting: Conditional Power.” In Interest Group Politics, 2nd ed., edited by Allan J. Cigler and Burdett A. Loomis. Washington, D.C.: Congressional Quarterly.

Evans, Diana. 1988. “Oil PACs and Aggressive Contribution Strategies.” Journal of Politics 50: 1047-1056.

Feldstein, Paul J., and Glenn Melnick. 1984. "Congressional Voting Behavior on Hospital Legislation: An Exploratory Study.” Journal of Health Politics 8: 686-701.

Frendreis, John P., and Richard Waterman, 1986. "PAC Contributions and Legislative Behavior: Senate Voting on Trucking Deregulation.” Social Science Quarterly 66: 401-412.

Grenzke, Janet M. 1989. "PACS and the Congressional Supermarket: The Currency is Complex.” American Journal of Political Science 33: 1-24. 
Grier, Kevin, and Michael Munger. 1986. "The Impact of Legislator Attributes on Interest-Group Campaign Contributions." Journal of Labor Research 7: 349-361.

Grier, Kevin B., and Michael C. Munger. 1991. "Committee Assignments, Constituent Preferences, and Campaign Contributions.” Economic Inquiry 29: 24-43.

Grier, Kevin B., and Michael C. Munger. 1993. "Corporate, Labor, and Trade Association Contributions to the U.S. House and Senate, 1978-1986." Journal of Politics 55: 615-44

Grier, Kevin B., Michael C. Munger, and Brian E. Roberts. 1994. "The Determinants of Industry Political Activity, 1978-1986.” American Political Science Review 88: 911926.

Grossman, Gene M., and Elhanan Helpman. 1994. "Protection for Sale.” American Economic Review 84: 833-850.

Grossman, Gene M., and Elhanan Helpman. 2001. Special Interest Politics, Cambridge MA and London UK: The MIT Press.

Hall, Richard L., and Frank W. Wayman. 1990. "Buying Time: Moneyed Interests and the Mobilizations of Bias in Congressional Committees." American Political Science Review 3: 797-820. 
Hansen, Wendy L., and Kee Ok Park. 1995. "Nation-State and Pluralistic Decision Making in Trade Policy: The Case of the International Trade Administration." International Studies Quarterly 39: 181-211.

Helpman, Elhanan, and Torsten Persson. 2001. "Lobbying and Legislative Bargaining." Advances in Economic Analysis and Policy 1, article 3.

Herndon, James. 1982. “Access, Record, and Competition as Influences on Interest Group Contributions to Congressional Campaigns.” Journal of Politics 44: 996-1019.

Jacobson, Gary C. 1980. Money in congressional elections. New Haven, CT: Yale University Press.

Johnson, Linda L. 1985. "The Effectiveness of Savings and Loan Political Action Committees." Public Choice 46: 289-304.

Jones, Woodrow, Jr., and K. Robert Keiser. 1987. "Issue Visibility and the Effects of PAC Money.” Social Science Quarterly 68: 170-176.

Kau, James B., and Paul H. Rubin. 1981. "The Impact of Labor Unions on the Passage of Economic Legislation.” Journal of Labor Research 2: 133-145. 
Kau, James B., and Paul H. Rubin. 1984. "Economic and Ideological Factors in Congressional Voting: The 1980 Election." Public Choice 44: 385-388.

Kau, James B., Donald Keenan, and Paul H. Rubin. 1982. “A General Equilibrium Model of Congressional Voting." Quarterly Journal of Economics 97: 271-293.

Kroszner, Randall S., and Thomas Stratmann. 1998. "Interest Group Competition and the Organization of Congress: Theory and Evidence from Financial Services Political Action Committees.” American Economic Review 88: 1163-87.

Kroszner, Randall S., and Thomas Stratmann. 2000. "Congressional Committees as Reputation-Building Mechanisms: Repeat PAC Giving and Seniority on the House Banking Committee.” Business and Politics, 2: 35-52.

Langbein, Laura I. 1986. “Money and Access: Some Empirical Evidence.” Journal of Poltiics 48: 1052-62.

Langbein, Laura I. 1993. "PACs, Lobbies, and Political Conflict: The Case of Gun Control." Public Choice 75: 254-271.

Langbein, Laura I., and Mark Lotwis. 1990. “The Political Efficacy of Lobbying and Money: Gun Control in the U.S. House, 1986." Legislative Studies Quarterly 15: 413440. 
Levitt, Steven D. 1994. "Using Repeat Challengers to Estimate the Effect of Campaign Spending on Election Outcomes in the U.S. House.” Journal of Political Economy 102: 777-798.

Levitt, Steven D. 1996. "How Do Senators Vote? Disentangling the Role of Voter Preferences, Party Affiliation, and Senator Ideology.” American Economic Review 86: 425-441.

Lott, John R., Jr. 2000. “A Simple Explanation for Why Campaign Expenditures Are Increasing: The Government is Getting Bigger." Journal of Law and Economics 43: 359-xxx.

Marks, Stephen V. 1993. "Economic Interests and Voting on the Omnibus Trade Bill of 1987." Public Choice 75: 21-42.

Marx, Leslie and Steve Matthews, "Dynamic Voluntary Contributions to a Public Project," Review of Economic Studies, v 62(2), 2000, 327-58.

Mayer, Kenneth R. 1991. The Political Economy of Defense Contracting. New Haven, CT: Yale University Press.

McArthur, John, and Stephen V. Marks. 1988. "Constituent Interest vs. Legislator Ideology: The Role of Political Opportunity Cost.” Economic Inquiry 26: 461-470. 
Milyo, Jeffrey, David Primo, and Timothy Groseclose. 2000. "Corporate PAC Campaign Contributions in Perspective.” Business and Politics 2: 75-88.

Nollen, Stanley D., and Dennis P. Quinn. 1994. "Free Trade, Fair Trade, Strategic Trade, and Protectionism in the U.S. Congress, 1987-88." International Organization 48: 491-525.

Neustadtl, Alan. 1990. "Interest-Group PACsmanship: An Analysis of Campaign Contributions, Issue Visibility, and Legislative Impact.” Social Forces 69: 549-564.

Peltzman, Sam. 1984. "Constituent Interest and Congressional Voting.” Journal of Law and Economics 27: 181-210.

Poole, Keith T., and Howard Rosenthal. 1984. "The Polarization of American Politics." Journal of Politics 46: 1061-1079.

Poole, Keith T., and Howard Rosenthal. 1997. Congress: A Political-Economic History of Roll Call Voting. Oxford: Oxford University Press.

Poole, Keith T., and Thomas Romer. 1985. "Patterns of Political Action Committee Contributions to the 1980 Campaigns for the U.S. House of Representatives." Public Choice 47:63-112. 
Poole, Keith T., Thomas Romer, and Howard Rosenthal. 1987. "The Revealed Preferences of Political Action Committees.” American Economic Review 77:298-302.

Romer, Thomas, and James M. Snyder, Jr. 1994. “An Empirical Investigation of the Dynamics of PAC Contributions.” American Journal of Political Science 38: 745-769.

Rosenstone, Steven J., and John Mark Hansen. 1992. Mobilization, Participation, and Democracy in America. New York: MacMillan Publishing Co.

Rothenberg, Lawrence S. 1992. Linking Citizens to Government: Interest Group Politics at Common Cause. Cambridge: Cambridge University Press.

Sabato, Larry. 1984. PAC Power. New York: W.W. Norton.

Saltzman, Gregory M. 1987. "Congressional Voting on Labor Issues: The Role of PACs." Industrial and Labor Relations Review 40: 163-179.

Schroedel, Jean R. 1986. “Campaign Contributions and Legislative Outcomes.” Western Political Quarterly 39: 371-389.

Silberman, Jonathan I., and Garey Durden. 1976. "Determining Legislative Preferences on the Minimum Wage: An Economic Approach.” Journal of Political Economy 84:

317-329. 
Snyder, James M., Jr. 1990. “Campaign Contributions as Investments: The House of Representatives, 1980-86.” Journal of Political Economy 98: 1195-1227.

Snyder, James M., Jr. 1992. “Long-Term Investing in Politicians, or Give Early, Give Often.” Journal of Law and Economics 35: 15-44.

Snyder, James M., Jr. 1993. “The Market for Campaign Contributions: Evidence for the U.S. Senate, 1980-1986.” Economics and Politics 5: 219-240.

Sorauf, Frank. 1988. Money in American Elections. Glenview, IL: Scott, Foresman and Company.

Sorauf, Frank J. 1992. Inside Campaign Finance: Myths and Realities. New Haven, CT: Yale University Press.

Stevens, Allison. 2001. "Despite Terrorism, Candidates Make Slow Return to Fundraising." The Hill, October 24 (www.hillnews.com/102401).

Stratmann, Thomas. 1991. "What Do Campaign Contributions Buy? Deciphering Causal Effects of Money and Votes.” Southern Economic Journal 57: 606-620.

Stratmann, Thomas. 1995. "Campaign Contributions and Congressional Voting: Does the 
Timing of Contributions Matter?” Review of Economics and Statistics 77: 127-136.

Stratmann, Thomas. 2002. “Can Special Interests Buy Congressional Votes? Evidence from Financial Services Legislation.” Journal of Law and Economics, forthcoming.

Tosini, Suzanne C., and Edward Tower. 1987. "The Textile Bill of 1985: Determinants of Congressional Voting Patterns.” Public Choice 54: 19-25.

Tullock, Gordon. 1972. “The Purchase of Politicians.” Western Economic Journal 10: $354-355$.

U.S. Census Bureau. 2000. Consolidated Federal Funds Report, 2000, $<$ http://www.census.gov/govs/cffr/00cffus.htm>.

U.S. Department of Agriculture website, <http://www.usda.gov/agencies/agencies.html $>$.

U.S. General Accounting Office (1993), "Sugar Program: Changing Domestic and International Conditions Require Program Changes" (April): GAO/RCED-93-84.

Verba, Sidney, Kay Lehman Schlozman, and Henry E. Brady. 1995. Voice and Equality: Civic Voluntarism and American Politics. Cambridge, MA: Harvard University Press. 
Vesenka, Mary H. 1989. “Economic Interests and Ideological Conviction: A Note on PACs and Agricultural Acts." Journal of Economic Behavior and Organization 12: 259-263.

Wayman, Frank W. 1985. "Arms Control and Strategic Arms Voting in the U.S. Senate: Patterns of Change, 1967-1983.” Journal of Conflict Resolution 29: 225-251.

Welch, William P. 1982. "Campaign Contributions and Legislative Voting: Milk Money and Dairy Price Supports.” Western Political Quarterly 35: 478-495.

Wilhite Allen, and John Theilmann. 1987. "Labor PAC Contributions and Labor Legislation: A Simultaneous Logit Approach.” Public Choice 53: 267-76.

Wright, John R. 1985. "PACs , Contributions, and Rolls Calls: An Organizational Perspective." American Political Science Review 79: 400-14.

Wright, John R. 1989. "PAC Contributions, Lobbying, and Representatives.” Journal of Politics 51: 713-29.

Wright, John R. 1990. “Contributions, Lobbying, and Committee Voting in the U.S. House of Representatives.” American Political Science Review 84: 417-38. 


\begin{tabular}{|c|c|c|c|c|c|}
\hline \multicolumn{6}{|c|}{ Summary of Roll-Call Voting Studies } \\
\hline Study & Issues Covered & $\begin{array}{l}\# \\
\text { Votes }\end{array}$ & IV? & $\begin{array}{l}\text { \# Sig PAC } \\
\text { Coeffs }\end{array}$ & $\begin{array}{l}\text { Ideology or } \\
\text { Party Sig? }\end{array}$ \\
\hline Silberman, Durden (1976) & minimum wage & 2 & No & $2 / 2$ & Yes \\
\hline Chappell (1981) & cargo preference & 1 & Yes & $4 / 8$ & Yes \\
\hline Kau, Rubin (1981) & various economic & 8 & Yes & $9 / 48$ & Yes \\
\hline Kau, Kennan, Rubin (1982) & various economic & 8 & Yes & $5 / 26$ & Yes \\
\hline Chappell (1982) & variety & 7 & Yes & $0 / 8$ & Yes \\
\hline Welch (1982) & dairy subsidy & 1 & Yes & $2 / 4$ & Yes \\
\hline Evans (1986) & tax, Chrysler & 8 & No & ?/16* & Yes \\
\hline Kau, Rubin (1984) & variety & 10 & Yes & $10 / 30$ & $\mathrm{n} / \mathrm{r}$ \\
\hline Peltzman (1984) & variety & 333 & No & $5 / 12$ & Yes \\
\hline Feldstein, Melnick (1984) & health care & 1 & No & $1 / 1$ & Yes \\
\hline Coughlin (1985) & domestic content & 2 & No & $2 / 2$ & Yes \\
\hline Johnson (1985) & bank, real estate & 9 & Yes & $11 / 45$ & Yes \\
\hline Wright (1985) & variety & 5 & No & $? / 5^{* *}$ & Yes \\
\hline Wayman (1985) & arms control & 19 & No & $1 / 13$ & Yes \\
\hline Frendreis, Waterman (1985) & trucking & 4 & No & $2 / 2$ & Yes \\
\hline Schroedel (1986) & banking & 3 & No & $3 / 5$ & Yes \\
\hline Wilhite, Theilmann (1987) & labor & 2 & Yes & $2 / 2$ & Yes \\
\hline Tosini, Tower (1987) & trade (textiles) & 1 & No & $1 / 2$ & Yes \\
\hline Jones, Keiser (1987) & labor & 1 & No & $5 / 5$ & Yes \\
\hline Saltzman (1987) & labor & 1 & Yes & $2 / 2$ & Yes \\
\hline MacArthur, Marks (1988) & domestic content & 1 & No & $1 / 1$ & Yes \\
\hline
\end{tabular}




\begin{tabular}{|c|c|c|c|c|c|}
\hline Grenzke (1989) & variety & 30 & Yes & $6 / 100$ & Yes \\
\hline Vesenka (1989) & agriculture & 14 & No & $4 / 14$ & Yes \\
\hline Neustadl (1990) & labor, business & 2 & No & $4 / 8$ & Yes \\
\hline Wright (1990) & tax, agriculture & 2 & No & $0 / 4$ & No \\
\hline Langbein, Lotwis (1990) & gun control & 6 & No & $2 / 3$ & Yes \\
\hline Durden et al. (1991) & strip mining & 3 & No & $2 / 2$ & Yes \\
\hline Mayer (1991) & aircraft carriers & 1 & No & $0 / 1$ & Yes \\
\hline Stratmann (1991) & agriculture & 10 & Yes & $8 / 10$ & Yes \\
\hline Rothenberg (1992) & MX missile & 8 & No & $1 / 8$ & Yes \\
\hline Langbein (1993) & gun control & 6 & No & $0 / 5$ & Yes \\
\hline Marks (1993) & trade & 5 & No & $2 / 5$ & Yes \\
\hline Nollen, Quinn (1994) & trade & 6 & No & $3 / 18$ & Yes \\
\hline Stratmann (1995) & agriculture & 10 & Yes & $13 / 20$ & Yes \\
\hline Bronars, Lott (1997) & variety & 35 & No & $5 / 50$ & Yes \\
\hline Stratmann (2002) & banking & 2 & No & $6 / 6$ & Yes \\
\hline \multicolumn{6}{|c|}{$\mathrm{n} / \mathrm{r}=$ not reported; $\mathrm{n} / \mathrm{i}=$ not included. } \\
\hline \multicolumn{6}{|c|}{ \# Sig PAC Coeffs column: The first number gives the number of coefficients on PAC contribution } \\
\hline \multicolumn{6}{|c|}{ variables that are statistically significant at the .05 level (two-tailed test) and have the predicted } \\
\hline \multicolumn{6}{|c|}{ sign. The second number gives the total number of PAC contribution variables in the analysis. } \\
\hline \multicolumn{6}{|c|}{ * Reports that, "PAC contributions were usually among the less important influences on House } \\
\hline \multicolumn{6}{|c|}{ members' voting on the two bills" (p. 126). } \\
\hline \multicolumn{6}{|c|}{ ** Reports that, "In none of the five cases examined were campaign contributions an important } \\
\hline \multicolumn{6}{|c|}{ enough force to change the legislative outcomes from what they would have been without any } \\
\hline contributions & & & & & \\
\hline
\end{tabular}




\begin{tabular}{|l|l|l|l|l|l|l|l|}
\hline \multicolumn{7}{|c|}{ Table 2. } \\
Dell Call Voting in the U.S. House, 1978-1994 \\
\hline \\
\hline
\end{tabular}




\begin{tabular}{|l|c|c|}
\hline \multicolumn{3}{|c|}{ Table 3. } \\
Campaign Spending in Gubernatorial Races, 1976-2000 \\
Dep. Var. = Log of Total Spending By All Candidates, Per-Capita \\
\hline Log of Personal Income, Per-Capita & $1.07^{* *}$ & $1.17^{*}$ \\
& $(.31)$ & $(.50)$ \\
\hline Log of State Government Spending, Per-Capita & - & -.09 \\
& & $(.32)$ \\
\hline Log of Population & -.33 & -.31 \\
& $(.36)$ & $(.36)$ \\
\hline Closeness in General Election & $2.93^{* *}$ & $2.92^{* *}$ \\
& $(.39)$ & $(.39)$ \\
\hline Democrat is Incumbent & $-.29^{* *}$ & -.29 \\
& $(.07)$ & $(.07)$ \\
\hline Republican is Incumbent & -.14 & -.14 \\
\hline Average Closeness in 1st Primary & $(.08)$ & $(.08)$ \\
\hline & $.91^{* *}$ & $.92^{* *}$ \\
& $(.21)$ & $(.21)$ \\
\hline & $1.11^{* *}$ & $1.09^{* *}$ \\
& $(.46)$ & $(.46)$ \\
\hline Observations & .41 & .41 \\
\hline
\end{tabular}


OLS estimates with state fixed-effects.

Standard errors in parentheses.

$*=$ significant at the .05 level.

$* *$ significant at the .01 level. 


\begin{tabular}{|l|c|c|c|c|}
\hline \multicolumn{5}{|c|}{ Table 4. } \\
\hline & Low Income & Mid. Income & High Income & Overall \\
\hline Margin $>30 \%$ & $\$ 353,000$ & $\$ 423,000$ & $\$ 522,000$ & $\$ 396,000$ \\
& $(139)$ & $(114)$ & $(23)$ & $(276)$ \\
\hline $15<$ Margin $<30$ & $\$ 476,000$ & $\$ 612,000$ & $\$ 705,000$ & $\$ 570,000$ \\
& $(241)$ & $(265)$ & $(85)$ & $(591)$ \\
\hline $5<$ Margin $<15$ & $\$ 900,000$ & $\$ 988,000$ & $\$ 1,269,000$ & $\$ 982,000$ \\
& $(248)$ & $(261)$ & $(66)$ & $(575)$ \\
\hline Margin $<5 \%$ & $\$ 1,192,000$ & $\$ 1,398,000$ & $\$ 1,700,000$ & $1,348,000$ \\
& $(121)$ & $(138)$ & $(34)$ & $(293)$ \\
\hline High Income $=$ Per-Capita Income $>\$ 19,000$. & & $(1,735)$ \\
\hline Overall & $\$ 709,000$ & $\$ 850,000$ & $1,026,000$ & $\$ 810,403$ \\
& $(749)$ & $(778)$ & $(208)$ & \\
\hline Number of observations in parentheses. & & \\
\hline \\
Middle Income $=\$ 13,000<$ Per-Capita Income $<\$ 19,000$. & \\
\hline
\end{tabular}




\section{Figure 1A}

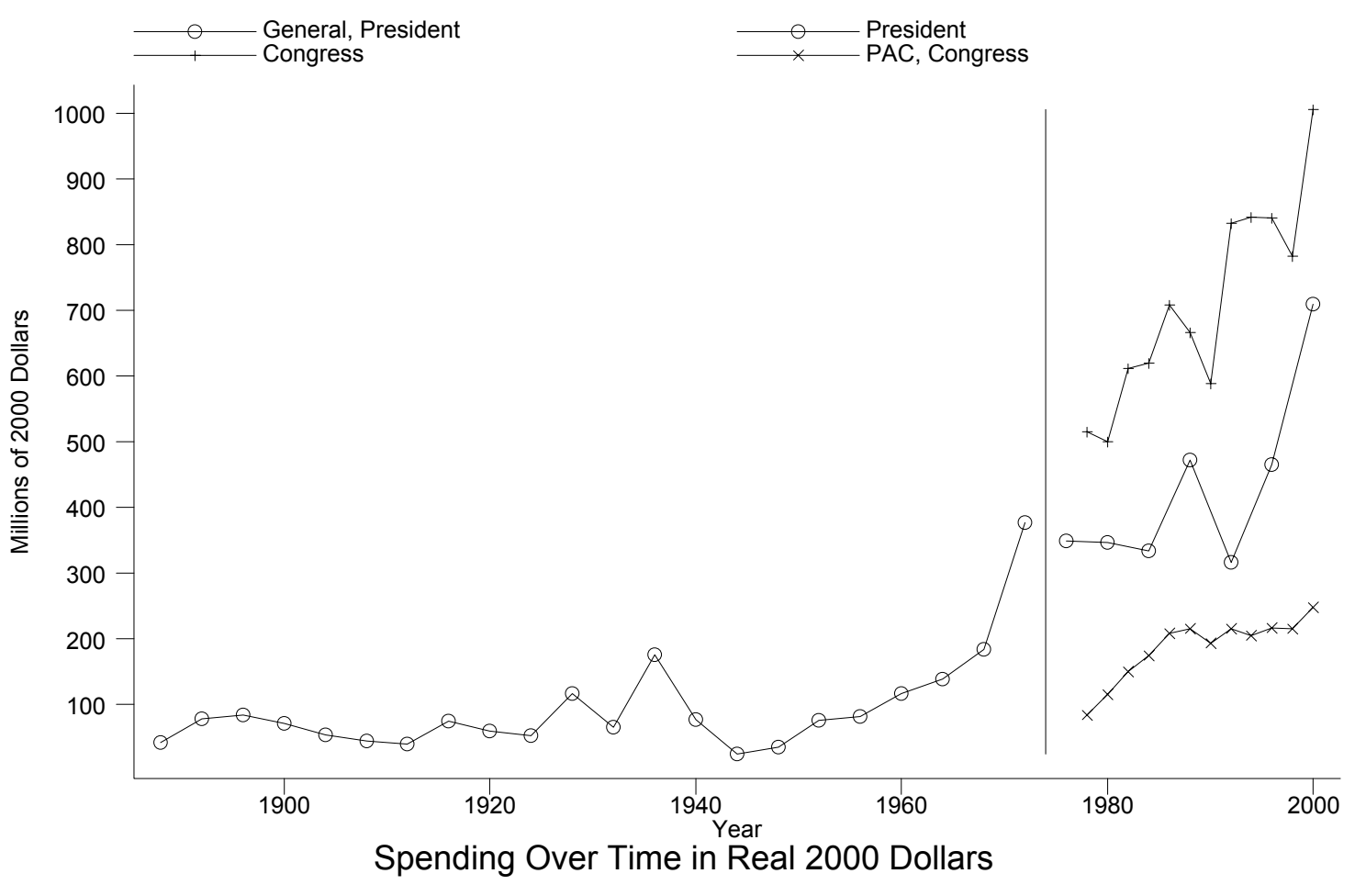

Figure 1B 


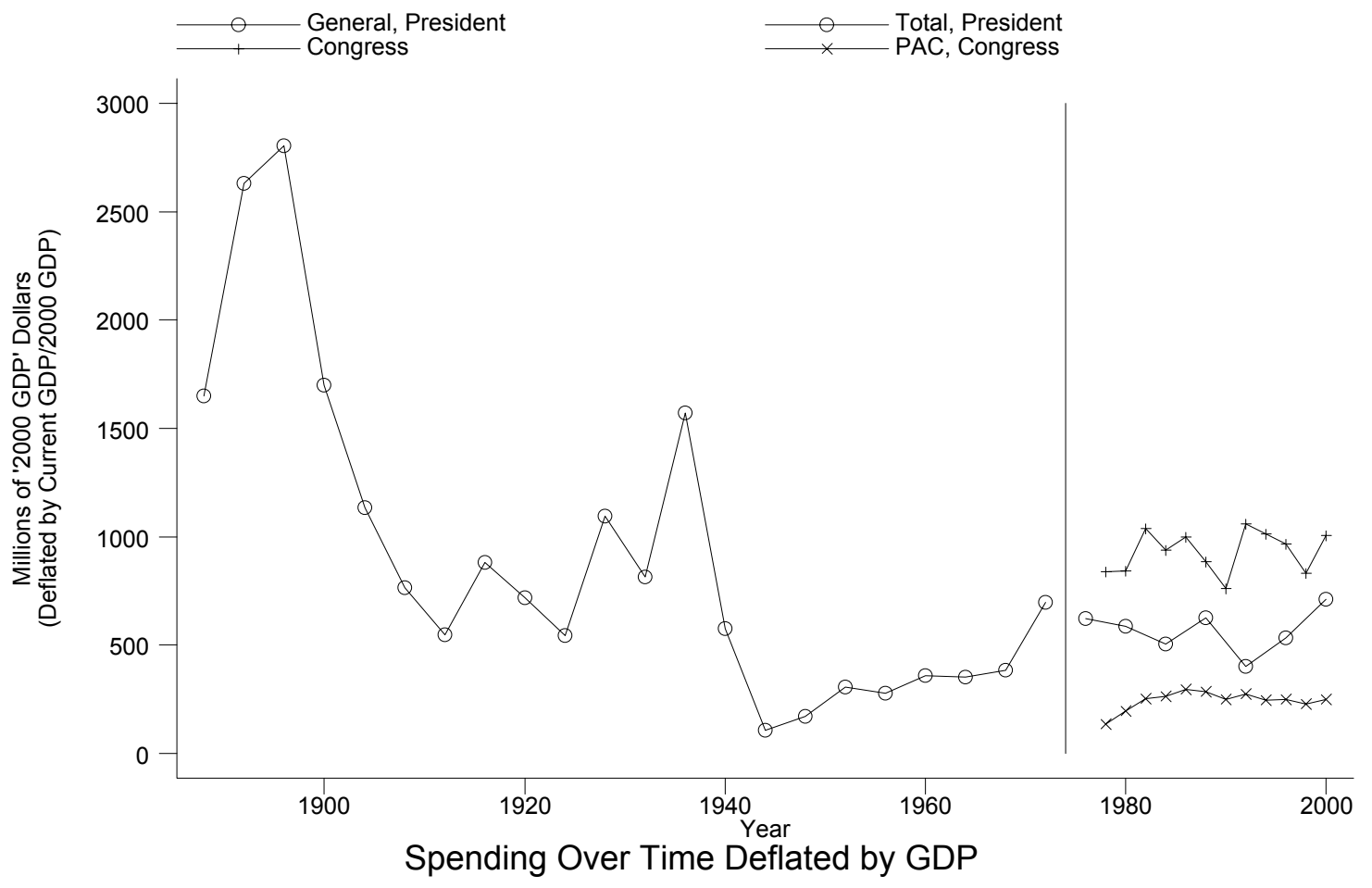


Endnotes

${ }^{1}$ An earlier version of this paper was entitled "Why Is There So Little Money In Politics?"

${ }^{2}$ Grossman and Helpman (2001) survey the variety of theoretical arguments along these lines.

3 Party accounts are the difficult to analyze, because transfers between party accounts may result in some money being double-counted. Transfers between party accounts amount to approximately 10 percent of all party money. Thus, the $\$ 1.2$ billion that flowed through party accounts probably represented about $\$ 1$ billion in actual campaign expenditures.

4 The FEC does not provide a direct accounting of this figure because only the total amount of contributions under $\$ 200$ must be reported, not the specific donations. We estimated the total amount of soft money from firms and organizations (approximately $\$ 380$ million) using the individual donor files and on-line reports from the Federal Election Commission at $<$ http://www.fec.gov>.

${ }^{5}$ Estimates of total industry contributions come from the website of the Center for Responsive Politics at $<$ http://www.opensecrets.org $>$. They include donations from political action committees and from individuals employed in an industry. They include hard money contributions and soft money contributions (that is, contributions 
to parties rather than to canditates from corporate treasuries or by individuals). Because not all of this campaign-related giving can be viewed as a coordinated effort by a united special interest, we view these numbers as overestimates.

${ }^{6}$ Exceptions are Hall and Wayman (1990), who study effort on behalf of groups, and Langbein (1986), who study minutes spent with lobbyists. Hansen and Park (1995) study antidumping and countervailing duty decisions by the International Trade Administration and find that total PAC contributions by an industry typically have no effect on the industry's chances of obtaining a favorable decision.

${ }^{7}$ Many papers run a similar model many times, adding different variables to the model to check robustness. We count these as one regression equation. If the coefficients of interest in these nested models are signed correctly and statistically significant at the 5 percent level of significance for a two-tailed test in at least half the models, we count this as finding campaign contributions as statistically significant. We also consider the specification as "one regression" if there are only small changes to the speciffcation, such as a different measure of a control variable, such as ideology.

8 Two recent papers noted in Table 2 -- Bronars and Lott (1997) and Stratmann (2002) -- attempt to address this problem by employing member-specific fixed effects, but these papers reach opposite conclusions about the importance of contributions. 
${ }^{9}$ One concern with the party coefficient is that it might reflect party money or interest group contributions to parties. An extensive literature has examined the association between party loyalty in the legislature, party campaign contributions and expenditures in elections and the sources of party funds, but found no statistical association among these factors. Ansolabehere and Sndyer (2000b) summarizes this literature and conclude that parties target close races to elect their candidates, but they do not target people of particular ideologies or reward loyalists.

${ }^{10}$ The corporations are AT\&T, Boeing, Citigroup, Exxon Mobil, General Electric, General Motors, Home Depot, IBM, Microsoft, Pfizer, Verizon, and Wal-Mart. Data on executives and their compensation come from the ExecuComp Database. Data on contributions came from the Center for Responsive Politics at $<\mathrm{http}: / /$ www.opensecrets.org $>$.

11 If we analyze the data in total contributions and expenditures rather than per capita, the independent variable on population is highly significant with an elasticity of approximately 1 .

12 To correct for the skew in both district income and total spending, we convert spending and income into logarithmic scales. The elasticity of total spending in terms of per capita income is .43.

${ }^{13}$ There is surprisingly little evidence that lobbying influences policies. One analysis finds that academic earmarks are responsive to lobbying by universities located in areas with representation on the House Appropriations Committee (de Figueiredo and Silverman, 2002). 